\title{
Nutrient Analysis and Formulation of Antioxidant Enriched Wheat Flour and Formulation of Wheat based Recipes from COFA Flour
}

\author{
K. Kavitha ${ }^{* *}$ and M. Priya ${ }^{2}$ \\ ${ }^{1}$ Assistant Professor, Department of Foods and Nutrition, Vellalar College for Women, Erode - 638012, \\ Tamil Nadu, India; k.kavitha@vcw.ac.in \\ ${ }^{2}$ M. Phil. Scholar, Department of Foods and Nutrition, Vellalar College for Women, \\ Erode - 638012, Tamil Nadu, India
}

\begin{abstract}
Among the varieties of fruits and vegetables, carrot and orange have colorful flesh and antioxidant property. Nuts like almond have been increasingly paid attention on the basis of their nutritional aspects and powerful natural antioxidants, which provide various beneficial health effects. As a consequence, a successful combination of Carrot, Orange Flesh and Almond (COFA) were processed in to COFA flour. The prepared COFA flour was incorporated into wheat flour for enriching its nutritional quality. The antioxidant enriched wheat flour was used for recipe preparation. The physico-chemical analysis of flour and sensory evaluation were done to know the acceptability of developed wheat based recipes. The antioxidants vitamins like A, C and E had increased when compared with normal wheat flour. From the results it was found that the developed flour and recipes have not only improved in terms of nutritional value and health benefits, but also have high potential of being accepted by consumers.
\end{abstract}

Keywords: Antioxidant Vitamins, COFA Flour, Formulated Wheat Flour, Nutritional Value, Physico-Chemical Analysis, Sensory Evaluation

\section{Introduction}

Fruits and vegetables are very important to prevent many diseases. Vegetables especially have the antioxidants, minerals and photochemical in correct combination that helps to keep the blood sugar in balance and along with fruits buildup the immune system. Each color found in fruits and vegetables focus on building the immune system in its own way ${ }^{1}$. Foods rich in antioxidants may be good for heart. According to Bone ${ }^{2}$, "increased antioxidant intake by eating more nuts, seeds, legumes, fruits and vegetables may also help to lower risk of infections and some forms of cancer".

The nuts are excellent source of Vitamin E. Almond contains about $25 \mathrm{~g}$ of Vitamin E per $100 \mathrm{~g}$ (about 170\% of RDA). Vitamin E helps in lipid membrane integrity of mucus membrane and protects skin from harmful free radicals. It is also rich in dietary fiber, vitamins and minerals and packed with numerous healths' promoting phytochemical and is a kind of well balanced food-ensuring protection against diseases ${ }^{3}$.

The food fortification has been recognized as a safe and effective strategy to combat micronutrients malnutrition ${ }^{4}$. According to Hannon et $\mathrm{al}^{5}$, it can be a commercial choice to provide extra nutrients in a food or sometimes it is a public health policy, which aims to reduce numbers of people with dietary deficiencies in a population.

So an attempt was made to prepare antioxidants enriched flour to replenish the nutrients in order to give a new fortified product to the society. The objectives of 
the study are to formulate and evaluate the antioxidant enriched COFA flour incorporated wheat based recipes, to determine the sensory attributes, and to popularize the antioxidant enriched COFA flour incorporated chapathi mix to school going children (6-12 years).

\section{Methods and Materials}

\subsection{Collection and Proportion of Raw Materials for Making Flour}

The raw materials used for processing were procured from the local market. The exact proportion of raw materials like carrot, orange flesh and almond used for the COFA flour preparation is given in (Table 1).

Table 1. Proportion of raw material for making COFA flour

\begin{tabular}{|c|c|c|}
\hline S. No. & Raw Materials & Quantity \\
\hline 1 & Carrot & $1 \mathrm{~kg}$ \\
\hline 2 & Orange Flesh (Pulp) & $1 \mathrm{~kg}$ \\
\hline 3 & Almond & $100 \mathrm{~g}$ \\
\hline
\end{tabular}

\subsection{Preparation of COFA Flour}

Raw materials like carrot and orange flesh were dried in ideally set oven temperature of $125^{\circ} \mathrm{F}$ to $135^{\circ} \mathrm{F} / 52^{\circ} \mathrm{C}$ to

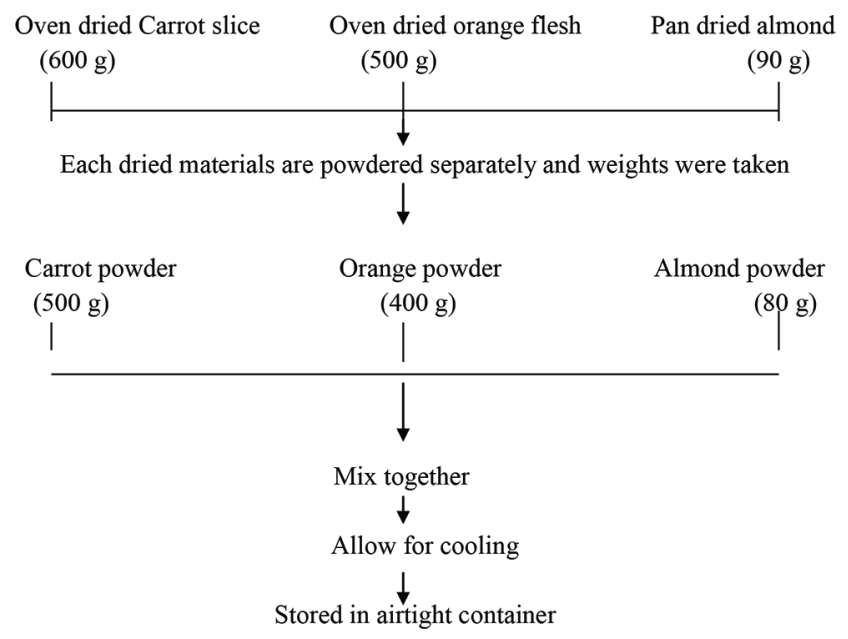

Figure 1. Preparation of COFA flour $57^{\circ} \mathrm{C}$ and $\left(125^{\circ} \mathrm{F}\right.$ to $\left.145^{\circ} \mathrm{F}\right)$. The almonds were roasted in a pan for 3 to 5 minutes and ingredients were stored in cool place.

When the food is dehydrated, $80 \%$ of the moisture is removed from fruits and up to $90 \%$ of the moisture is removed from vegetable making the dried weight of foods much less than the fresh weight. The prepared COFA flour was mixed with whole wheat flour and antioxidant enriched wheat flour is ready to use for recipe preparation.

The whole wheat grain was manually cleaned by winnowing and sifting to remove dust and other impurities. It was then milled in local mills and passed through a mesh size of $1 \mathrm{~mm}$ and were packed and stored in containers.

\subsection{Proportion and Preparation of Antioxidant Enriched Wheat based Recipes}

The proportion of ingredients used for chapathi, wheat dosa, wheat rotti and wheat adai are given in (Table 2) and (Table 3).

The antioxidant enriched COFA flour incorporated chapathi, wheat dosa and wheat rotti were prepared in different ratio like 90:10, 80:20, 70:30.

The antioxidant enriched COFA flour incorporated wheat adai was prepared with different ratio like 90:10, 80:20 and 70:30. The ingredients like small onion, Green chilies, Curry leaves, coriander leaves, salt and cooking oil $(25 \mathrm{~g}, 10 \mathrm{~g}, 2 \mathrm{~g}, 2 \mathrm{~g}, 2 \mathrm{~g}$ and $10 \mathrm{ml}$ respectively) were used for this preparation.

Table 2. Proportion of ingredients used for chapathi, wheat dosa and wheat rotti

\begin{tabular}{|c|c|c|c|c|c|}
\hline S.No. & Products & $\begin{array}{c}\text { Wheat } \\
\text { flour } \\
(\mathrm{g})\end{array}$ & $\begin{array}{c}\text { COFA } \\
\text { flour } \\
(\mathrm{g})\end{array}$ & $\begin{array}{c}\text { Salt } \\
(\mathrm{g})\end{array}$ & $\begin{array}{c}\text { Cooking } \\
\text { oil (ml) }\end{array}$ \\
\hline 1 & Control & 100 & - & 2 & 5 \\
\hline 2 & Variation-I & 90 & 10 & 2 & 5 \\
\hline 3 & Variation-II & 80 & 20 & 2 & 5 \\
\hline 4 & Variation-III & 70 & 30 & 2 & 5 \\
\hline
\end{tabular}


Table 3. Proportion of ingredients used for wheat adai

\begin{tabular}{|c|c|c|c|c|c|c|c|c|c|}
\hline S.No. & Product & $\begin{array}{c}\text { Wheat } \\
\text { flour }(\mathrm{g})\end{array}$ & $\begin{array}{c}\text { COFA } \\
\text { flour }(\mathrm{g})\end{array}$ & $\begin{array}{c}\text { Small } \\
\text { onion }(\mathbf{g})\end{array}$ & $\begin{array}{c}\text { Green } \\
\text { chillies }(\mathrm{g})\end{array}$ & $\begin{array}{c}\text { Curry } \\
\text { leaves }(\mathbf{g})\end{array}$ & $\begin{array}{c}\text { Coriander } \\
\text { leaves }(\mathbf{g})\end{array}$ & $\begin{array}{c}\text { Salt } \\
(\mathbf{g})\end{array}$ & $\begin{array}{c}\text { Cooking oil } \\
(\mathbf{m l})\end{array}$ \\
\hline 1 & Control & 100 & - & 25 & 10 & 2 & 2 & 2 & 10 \\
\hline 2 & Variation I & 90 & 10 & 25 & 10 & 2 & 2 & 2 & 10 \\
\hline 3 & Variation II & 80 & 20 & 25 & 10 & 2 & 2 & 2 & 10 \\
\hline 4 & Variation III & 70 & 30 & 25 & 10 & 2 & 2 & 2 & 10 \\
\hline
\end{tabular}

\subsection{Nutrient Analysis, Storage Stability and Microbial Content of COFA Flour using Different Containers}

The antioxidant vitamins like A, C, E and other nutrients like carbohydrates, protein, fat, ash, moisture, calcium, iron and fiber were analyzed using standard procedure $^{6}$.

Control and experimental flour were packed and sealed in airtight containers (plastic, silver container and polyethylene cover) and stored at room temperature $\left[30^{\circ} \mathrm{C}-35^{\circ} \mathrm{C}\right]$ for 60 days. The storage stability of COFA flour was evaluated initially on $0^{\text {th }}$ day and after 10,15 and 30 days from the date of preparation. The products were analyzed periodically for microbial content by determining standard count ${ }^{7}$.

\subsection{Sensory Evaluation}

The sensory quality of the developed product with respect to color, appearance, aroma, texture and taste was judged by twenty panelists using 5 -point hedonic scale ${ }^{8}$. The scores ranged from poor (1) to excellent (5).

\subsection{Consumer Acceptability}

Twenty panel members were selected from S. K. Medical Foundation at Erode district for testing the consumer acceptance of antioxidant enriched wheat based recipes, using 9-point hedonic rating scale ranging from "like extremely" to "dislike extremely" for each recipe.

\subsection{Popularization of Antioxidant Enriched Wheat-based Recipe among School going Children (6-12 Years)}

Forty school going children between the age group of 6-12 years (20 boys and 20 girls) from Vairapalayam Government Higher Secondary School, Erode were selected to popularize COFA flour enriched wheat-based recipes, after obtaining prior permission from School Head Master. Details regarding general information, socio economic status, food consumption pattern and knowledge about antioxidant enriched foods and nutrients deficiencies were collected from the selected children using interview schedule. Finally, the prepared wheat based recipes like chapathi, wheat dosa, wheat adai and wheat rotti were popularized among the selected school going children.

\subsection{Statistical Analysis}

The collected data was statistically analyzed using mean, standard deviation and t-test.

\section{Results and Discussion}

\subsection{Nutrient Content of COFA Flour}

The nutrients in the packs are chemically analyzed for antioxidants, vitamins like A, C, E and other nutrients like carbohydrates, protein, fat, moisture, ash, calcium and iron and presented in (Table 4).

The COFA flour was found to contain $700 \mu \mathrm{g}$ of vitamin A, $100 \mathrm{mg}$ of vitamin $\mathrm{C}$ and $1200 \mu \mathrm{g}$ vitamin E. Due to incorporation of COFA flour, the antioxidant vitamin content increased when compared with normal wheat flour.

\subsection{Organoleptic Evaluation of Antioxidant Enriched Wheat based Recipes}

The overall acceptability of $30 \%$ antioxidant enriched chapathi, wheat dosa, wheat adai and wheat rotti was highly acceptable and statistically there was no significant difference between control and all the variations. 
Table 4. Nutrient content of COFA flour

\begin{tabular}{|c|c|c|c|}
\hline S.No. & Nutrients & $\begin{array}{c}\text { Nutritive value } \\
\text { for 100 g of } \\
\text { COFA flour* }\end{array}$ & $\begin{array}{c}\text { Normal } \\
\text { wheat } \\
\text { flour/100 g }\end{array}$ \\
\hline & $\begin{array}{c}\text { Antioxidant } \\
\text { Vitamins }\end{array}$ & & \\
\hline 1 & Vitamin- A & $700 \mu \mathrm{g}$ & $29 \mu \mathrm{g}$ \\
\hline 2 & Vitamin- C & $100 \mathrm{mg}$ & $0 \mathrm{mg}$ \\
\hline 3 & Vitamin- E & $1200 \mu \mathrm{g}$ & $0.2 \mu \mathrm{g}$ \\
\hline 4 & Other Nutrients & $32.2 \mathrm{~g}$ & $69.4 \mathrm{~g}$ \\
\hline 5 & Protein & $22.4 \mathrm{~g}$ & $12.1 \mathrm{~g}$ \\
\hline 6 & Fat & $58.2 \mathrm{~g}$ & $1.7 \mathrm{~g}$ \\
\hline 7 & Calcium & $540 \mathrm{mg}$ & $48 \mathrm{mg}$ \\
\hline 8 & Iron & $160 \mathrm{mg}$ & $4.9 \mathrm{mg}$ \\
\hline 9 & Moisture & $8.6 \mathrm{~g}$ & $12.2 \mathrm{~g}$ \\
\hline 10 & Ash & $1.9 \mathrm{~g}$ & $0.4 \mathrm{~g}$ \\
\hline 11 & Fibre & $6.4 \mathrm{~g}$ & $1.9 \mathrm{~g}$ \\
\hline
\end{tabular}

*COFA flour - Carrot Orange Flesh and Almond flour

\subsection{Nutritive Value of Formulated Antioxidant Enriched Recipes}

The nutrient content of the products like chapathi, wheat dosa and wheat adai and wheat rotti is presented in the (Table 5).

From the results, it was observed that COFA flour enriched recipes provided more antioxidants and other nutrients especially protein, iron, calcium and energy.

\subsection{Microbial Count and Storage Stability of Antioxidant Enriched Wheat Flour}

The following (Table 6) describes the microbial storage stability of formulated flour.

Table 6. Microbial count of antioxidant enriched wheat flour

\begin{tabular}{|c|c|c|c|c|}
\hline \multirow{2}{*}{$\begin{array}{c}\text { Name of the } \\
\text { Product }\end{array}$} & \multicolumn{4}{|c|}{ Total viable Bacteria in cfu/g } \\
\cline { 2 - 5 } & Initial & $\mathbf{1 0}^{\text {th }}$ day & $\mathbf{1 5}^{\text {th }}$ day & $\mathbf{3 0}^{\text {th }}$ day \\
\hline $\begin{array}{c}\text { Antioxidant } \\
\text { enriched } \\
\text { Wheat flour }\end{array}$ & $0 \times 10^{2}$ & $0 \times 10^{2}$ & $1 \times 10^{3}$ & $1 \times 10^{3}$ \\
\hline
\end{tabular}

From the above Table, it was noted that the microbial count of antioxidant enriched wheat flour at the initial and $10^{\text {th }}$ day was $0 \times 10^{2} \mathrm{cfu} / \mathrm{g}$, after $15^{\text {th }}$ day and $30^{\text {th }}$ day it showed slight increase in count, however was within the acceptable limits.

The storage stability of the formulated antioxidant enriched wheat flour was assessed with different containers. It was noted s there was no change in flavor and taste in COFA flour. The antioxidant enriched wheat flour stored in plastic container received maximum score than the storage in polyethylene cover and silver container. On microbial analysis, there was minimum microbial growth in plastic container than the polyethylene cover and silver container. Hence, it can be stored up to 30 days at room temperature as well as in refrigerator.

\subsection{Consumer Acceptability of Formulated Antioxidant Enriched Recipes}

Consumer acceptability of formulated antioxidant enriched wheat based recipe, showed that mean overall

Table 5. Nutritive value of formulated antioxidant enriched recipes

\begin{tabular}{|c|c|c|c|c|c|c|c|c|c|c|c|}
\hline \multirow[b]{2}{*}{ S.No } & \multirow{2}{*}{$\begin{array}{c}\text { Name of } \\
\text { Recipes }(100 \mathrm{~g})\end{array}$} & \multicolumn{10}{|c|}{ Nutrient Present in the Recipes Per 100 gm } \\
\hline & & $\begin{array}{l}\text { Energy } \\
\text { (Kcal) }\end{array}$ & $\begin{array}{l}\text { Protein } \\
\text { (g) }\end{array}$ & $\begin{array}{l}\text { Fat } \\
\text { (g) }\end{array}$ & $\begin{array}{l}\mathrm{CHO} \\
\text { (g) }\end{array}$ & $\begin{array}{c}\text { Vit- A } \\
(\mu \mathrm{g})\end{array}$ & $\begin{array}{l}\text { Vit- C } \\
\text { (mg) }\end{array}$ & $\begin{array}{c}\text { Vit- E } \\
(\mu g)\end{array}$ & $\begin{array}{c}\text { Calcium } \\
\text { (mg) }\end{array}$ & $\begin{array}{l}\text { Iron } \\
(\mathrm{mg})\end{array}$ & $\begin{array}{c}\text { Fibre } \\
\text { (g) }\end{array}$ \\
\hline 1 & Chapathi & 673 & 49.5 & 110 & 64.9 & 732 & 103 & 1300 & 602 & 170 & 9.8 \\
\hline 2 & Wheat dosa & 673 & 49.5 & 110 & 64.9 & 732 & 103 & 1300 & 602 & 170 & 9.8 \\
\hline 3 & Wheat adai & 720 & 62.0 & 125 & 73.2 & 1298 & 126 & 1312 & 632 & 178 & 12.1 \\
\hline 4 & Wheat rotti & 673 & 49.5 & 110 & 64.9 & 732 & 103 & 1300 & 602 & 170 & 9.8 \\
\hline
\end{tabular}


acceptability of chapathi was $8.3 \pm 1.19$, wheat dosa was $7.6 \pm 1.04$, wheat adai was $9.2 \pm 1.39$ and wheat rotti was $8.1 \pm 1.15$. Among all the wheat based recipes wheat adai received high score than the other recipes.

\section{Conclusion}

The major implication of this research is that the COFA flour can be efficient strategy to improve the antioxidant content of wheat flour with enhancement of health linked functionality. From the above results it may be concluded that COFA flour enriched wheat flour have appreciable amount of antioxidant level and also other nutrients like protein, iron, calcium and fiber. The formulated recipes were highly acceptable by the consumer. Hence, the COFA flour enriched wheat flour can be given for the infants and young children for the improvement of their health. The cost of the flour is also low and economic.

\section{Reference}

1. Ahlberg. Health benefits of vegetables. Annual Review of Nutrition. 2010; 23:171.

2. Bone RA. Benefits of colored fruits. Journals of Plant Science. 2003; 42:58.

3. Bowden. Health benefits of almonds. Journal of Food Biochemistry. 2010; 33:38-9.

4. Benzie I. Evaluation of dietary antioxidants. Comparative Biochemistry and Physiology. 2010; 36:113-26. https:// doi.org/10.1016/S1095-6433(02)00368-9

5. Hannon, Lund, Ruxton. The impact of voluntary fortification of foods on micronutrients. Public Health Nutrition. 2007; 11(8):807-21.

6. Official Methods of Analysis of AOAC International. $16^{\text {th }}$ ed. Edited by Patricia Cuniff, Published by AoAC Int. Virginia.USA.Test; 1995. p. 3-4.

7. Bacteriological Analytical Manual. $6^{\text {th }}$ ed. Arlington, $V$. A. Association of Official Analytical Chemists for FDA, Washington D.C; 1992. p 17-21.

8. Srilakshmi B. Food Science. New Delhi: New Age International Publishers. $6^{\text {th }}$ ed. 2015. p 321. 